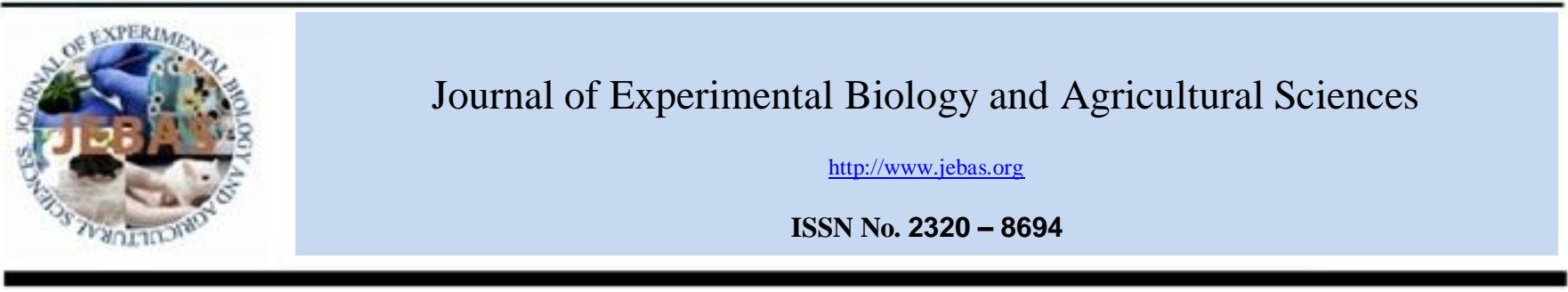

\title{
EFFECT OF VARIOUS SOIL SALINITY LEVEL ON THE ANTIOXIDANT AND PHYSIOLOGICAL PROPERTIES OF CORN PLANT (Zea mays)
}

\section{Ramin Ezzati $^{1}{ }^{*}$ and Mina Karimi ${ }^{2}$}

\footnotetext{
${ }^{1}$ Academic Staff, Assist. Assist. Prof. University of Kharazmi, Faculty of Biological Science, Department of Plant Biology. No 43. Mofateh Ave. Tehran/Iran ${ }^{2}$ Plant Physiology Msc. Stu. University of Kharazmi, Faculty of Biological Science,Department of Plant Biology. No 43. Mofateh Ave. Tehran/Iran
}

Received - June 22, 2015; Revision - July 11, 2015; Accepted - October 07, 2015

Available Online - October 20, 2015

DOI: http://dx.doi.org/10.18006/2015.3(5).448.452

\begin{abstract}
KEYWORDS
Soil salinity

Corn

Physiological parameters
\end{abstract}

* Corresponding author

E-mail: ezati2000@yahoo.com (RaminEzzati)

Peer review under responsibility of Journal of Experimental Biology and Agricultural Sciences.

Production and Hosting by Horizon Publisher (www.myvision.webs.com/horizon.html).

All rights reserved.
All the article published by (Journal of Experimental Biology and Agricultural Sciences) / CC BY-NC 4.0

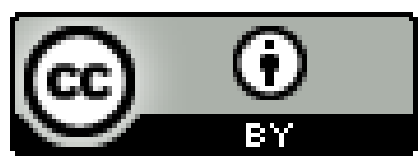




\section{Introduction}

In recent years, effect of desert soil has been increased in various parts of the world including Iran. The negative and destructive effects of these desert soils have been well reported and known to everyone but the positive effect of such dust as nutrient was reported by limited researchers (Dadkhah \& Griffiths, 2005; Emdad \& Fardad, 2000). Furthermore Dadkhah \& Griffiths (2005) reported a significant effect of such atmospheric suspended dust particle on the growth of wheat plant. Similarly, Swap et al. (1992) and Koren et al. (2006) reported a significant effect of desert soil on the fresh \& dry weight and height of plants. Productivity of Amazon basin and efficiency of its rainforests is owing to transport, 40 million tons of dust every year (Emdad \& Fardad, 2000).

According to Zhu \& Zhang (1997) high salinity is one of the major fundamental problems in many parts of the words and it became more serious problem in the irrigated cropping system, because of this half of irrigated lend are affected by salinity. Furthermore, Grattan \& Grieve (1992) reported that increasing the soil salinity have negative impact on the performance of root. In general, by increasing the degree of soils salinity reduced the plant growth and one of its possible reasons maybe reductions in the rate of photosynthesis per unit area. Also, reduction in leaf area and plant growth was also reported amongst the plant due to increasing soil salinity. Dry weight of plants shows downward trend by increasing salinity of soil and it is due to the impaired absorption of necessary food for plant growth. It was also reported that growth of shoots than roots are less affected by salinity Ezzati et al. (2011). Corn is considered as one of the most important corps in Iran and it is cultivated in 0.25 million hectares areas. Annual production of this crop was reported 1.65 million tons from Iran which was reported 2.8 percent of total cereal production (Ezzati et al., 2011). Large numbers of studies concluded the negative effect of soil salinity on the growth characteristic of plant but the information regarding the effect of soil salinity on the biochemical and physiological parameters of corn plant under Iranian climatic conditions are in scarcity therefore in present study by using different soils and maltodextrin, the corn was fostered and biochemical and physiological treated plants were measured and compared.

\section{Materials and Methods}

$250 \mathrm{~g}$ soil sample was collected from the desert of Libya, Iraq, India and Karaj desert of Iran for investigating the effect of these soils on the biochemical and physiological parameters of corn plant. Maize variety used in this study was developed by the Research Institute Alborz Province of seeds and seedlings. Study was conducted at research laboratory of School of Biological Sciences at the University of al-Khwarizmi The average temperature and humidity maintained under laboratory condition during study period was $25^{\circ} \pm 2 \mathrm{C}$ and $65 \%$ respectively while the water temperature was also maintain at $25{ }^{\circ} \mathrm{C}$. For identical corn cultivation, perlite medium was used during study period. In homogenized situation and by using 4 reactors with 8 -liter and 2 projectors with $3300 \mathrm{~m}^{2} / \mathrm{m}^{3}$ of climate and adequate moisture of 2 -valent iron was revived and it was placed to treat with corn.

All the selected desert soils were used as treatments while the growth of control plants was conducted by using Hoagland. Collected desert soils were kept in reactors at suitable light for 120 minutes, this process helped in the activation of available bacteria. The soil of Libyan Desert has elements of Niks, quartz, calcite and gypsum. Physiological parameters and the amount of enzymes were measured by using methods described by Ezzati et al. (2011). The physicochemical properties of collected soil samples were also measured by available standard methodology. The EC of the collected soil samples were measured by the method described by Smith \& Doran (1996) while the chemical analysis of collected soil samples were carried out by following the manual prepared by Haluschak (2006). Level of Glutathione peroxidase and Malondialdehyde enzyme were measured by method described in Boguslawska-Jaworska \& Kaplan (1969) and Dey et al. (2007) respectively.

\section{Results}

3.1 Physicochemical Properties of the collected desert soil

Results of $\mathrm{pH}$ and $\mathrm{EC}$ of the collected samples from deserts of Iraq, India, Karaj and control has been displaced in table 1. The highest degree of salinity ( $\mathrm{pH} 8.2$ ) and EC (46) was reported from the sample collected from the Libyan Desert soil, this $\mathrm{pH}$ and EC value was followed by the sample collected from Iraq desert. The lowest pH (7.39) and EC (16) was reported from the Karaj desert soil. The salinity and EC of Indian and Karaj desert soil was reported below than the Control. Chemical analyses of various areas desert soil are represented in table 2. Like soil $\mathrm{pH}$ and EC, Libyan Desert soil showed highest minerals nutrient level which favors the better plant growth. Among all the tested soil, soil collected from Karaj shows least nutrient availability while the soil of Indian and Iraq desert shows intermediate nutrient levels.

\subsection{Effect of desert soil on Plant growth characters}

Result of the study revealed highest fresh $(0.3201 \mathrm{~g})$ and dry weight $(0.0330 \mathrm{~g})$ from Libyan Desert soil and it was followed by Iraq desert soil. The lowest fresh and dry weight was reported from the Karaj soil and it is lower than control. While these two values for Indian desert are almost at par the control treatments (Table 3). 
Table 1 Measured PH and EC of the various dust samples collected from different areas

\begin{tabular}{|lcc|} 
Desert soil Samples & $\mathrm{pH}$ & $\mathrm{EC}(\mathrm{ds} / \mathrm{m})$ \\
\hline Libyan & 8.2 & 46 \\
\hline Iraq & 7.73 & 35 \\
\hline India & 7.44 & 19 \\
\hline Karaj & 7.39 & 16 \\
\hline Control & 7.5 & 27 \\
\hline
\end{tabular}

Table 2 Chemical analysis of collected dust from different Desert regions

\begin{tabular}{|c|c|c|c|c|c|c|c|c|}
\hline Soil Samples & $\mathrm{Fe}(\mathrm{mg} / \mathrm{l})$ & $\mathrm{NO}_{3}(\mathrm{mg} / \mathrm{l})$ & $\mathrm{Zn}(\mathrm{mg} / \mathrm{l})$ & $\mathrm{Cu}(\mathrm{mg} / \mathrm{l})$ & $\mathrm{Na}(\mathrm{meq} / \mathrm{l})$ & $\mathrm{Ca}(\mathrm{meq} / \mathrm{l})$ & $\operatorname{Cr}(\operatorname{meq} / \mathbf{l})$ & $\mathrm{so}_{4}{ }^{2-}(\mathrm{meq} / \mathrm{l})$ \\
\hline Libyan Desert & 1.07 & 170.1 & 0.68 & 0.07 & 41 & 30.1 & 0.27 & 2.4 \\
\hline Iraq & 0.44 & 165.8 & 0.52 & 0.05 & 31 & 26.1 & 0.22 & 2.1 \\
\hline India & 0.12 & 130.8 & 0.33 & 0.04 & 28 & 29.3 & 0.13 & 1.7 \\
\hline Karaj & 0.1 & 155.5 & 0.21 & 0.04 & 23 & 20.1 & 0.09 & 1.8 \\
\hline Control & 0.9 & 155.7 & 0.2 & 0.03 & 29.4 & 20 & 0.7 & 1.8 \\
\hline
\end{tabular}

\subsection{Effect of desert soil on enzymes level}

Effect of desert soil on the level of Glutathione peroxidase enzyme (GPx) was also evaluated in present study. Like other parameters here also negative effect of soil salinity level was not reported and the highest level was reported from highly saline soil of Libyan Desert. The enzymatic activity in the treatment containing dust of Iraq and India shows mild activity and not showing any significant differences between these two, the minimum amount of enzyme activity is related to control treatment (Figure 1).

Corn sample treated by dust of Libyan Desert showed lower level of Malondialdehyde (MDA). So the MDA level in plant treated by desert soil of Libya was almost half than the treatment of control. Treatment containing dust of Iraq and India shows MDH activity in one range and there was no significant differences reported. There is an inverse relation between the catalase enzyme and MDA (Figure 2).

\section{Discussions}

Electrical conductivity represents the availability of soluble salt in a soil. Like salt concentration, value of EC is also directly proportional to the salinity and highly saline soil has always higher EC. In present study highest $\mathrm{pH}$ and EC was reported from Libyan Desert soils. Findings of present study are in accordance with the finding of Patriquin et al. (1993) those have reported a positive effect of soil salinity on the EC, these researchers reported that. Similar type of findings was reported by Smith \& Doran (1996) and Anderson Cook et al. (2002).

Like EC and $\mathrm{pH}$, soil sample collected from Libyan Desert sows superiority over the other soil samples in available nutrients. Higher salt level of Libyan desert soil favor its high salinity and EC and in this manner finding of present study are in accordance the findings of Kumar (2008) those has reported that higher value of soil soluble salt has been represented by high salinity and EC.

Findings of this study clearly suggested that application of various areas desert soils did not have any negative impact on the plant growth and it influence fresh and dry weight of the corn plant. A comparison of plant length, fresh weight, dry weight of plant, EC and $\mathrm{pH}$ measurements suggested that degree of desert soil salinity did not showing any negative effect on plant growth and maximum length, wet and dry weight was reported from desert sample of Libyan Desert as compared to the other samples of Iraq, India and control. Although plant showed poor growth in highly saline desert soil but findings of present study are not showing any negative effect of desert soil on the growth of corn plant. While these soils were lead to increase of average wet weight of plant and increase the activity of guaiacol peroxidase enzyme.

Comparing salinity degree and plant growth characters, a positive correlation was observed between these two and highest plant growth was reported at the highly saline soil collected from the Libyan Desert. In present study plant grown in highly saline desert soil showed superiority over the less saline soil of Karaj Desert. These findings are similar to the finds of previous researchers; those have reported higher growth in desert soil (Zhu \& Zhang, 1997). This higher plant growth can be justified by the presence of higher salt concentration in Libyan Desert soil.

Antioxidant enzyme is considered as the fastest combatant units against the attack of active oxygen (Inze \& Montago, 2002 ). According to Vaughan \& Judd (2003), plants are affected by different stresses such as salinity, drought, tissue damage (scarring), ozone, UV etc during their life cycle. Salinity stress is one of the most important environmental factors to reduce the plant production. This may be due to the effect of soil salinity on physiology, growth and evolution of plants (Smith, 1995). 


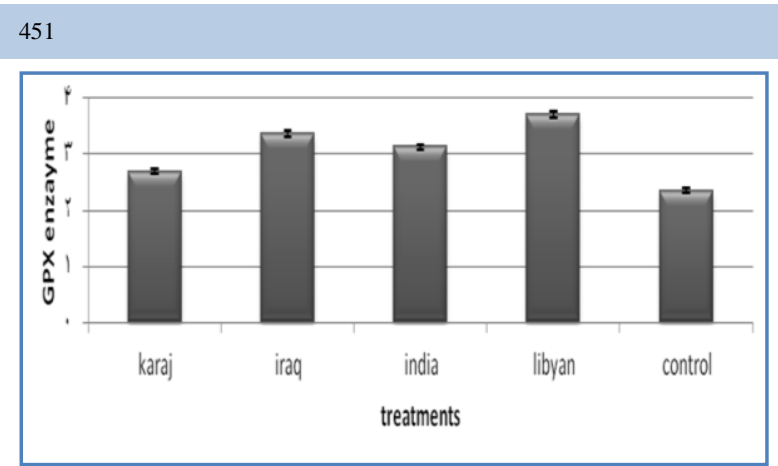

Figure 1 the GPX enzyme activity of sample of leaves of corn plant treated with collected dust from different countries
Ezzati and Karimi

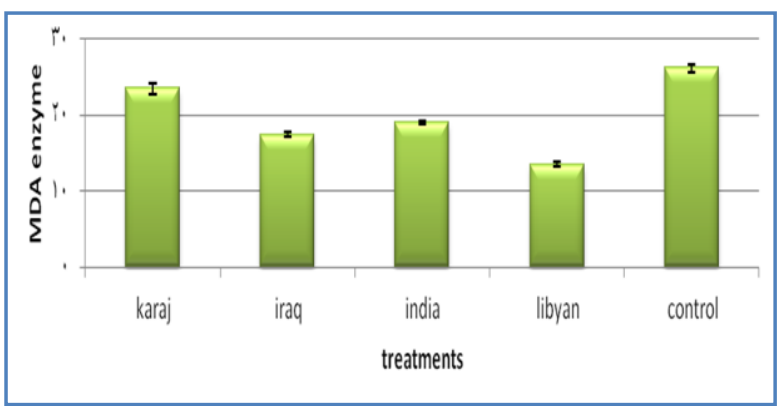

Figure 2 the MDA enzyme activity of leaves of corn plants treated with collected dust from different countries

Table 3 Fresh and dry weight of corn plant based on the different areas soil.

\begin{tabular}{lcc} 
Sample of Soil & Fresh Weight $(\mathrm{g})$ & Dry Weight $(\mathrm{g})$ \\
\hline Libyan & 0.3201 & 0.033 \\
\hline Iraq & 0.2702 & 0.0264 \\
\hline India & 0.2491 & 0.0229 \\
\hline Karaj & 0.1812 & 0.0177 \\
\hline control & 0.2308 & 0.0219
\end{tabular}

High salinity is one the most important agriculture problems in most of the part of world and more than half of irrigation systems in the world are affected by salinity (Zhu \& Zhang, 1997). Furthermore, Grattan \& Grieve (1992) reported that increasing in salinity of soil affect the performance of root possibly it will be decrease, also they reported a positive correlation between the salinity level and plant weight. In this manner finding of the present study are in accordance with the findings of Grattan \& Grieve (1992). Dadkhah \& Griffiths (2005) reported that by increasing the salinity degree of soil, the dry weight of plants show a descending trend and it is due to impaired absorption of nutrients required for plant growth. In this manner findings of present study are controversial to the findings of Dadkhah \& Griffiths (2005). In present study negative effect of saline soil was not reported and highly saline Libyan desert soil produced better growth results than the less saline soil. Foster (1991) reported that the growth of shoots are less affected by salinity than the roots growth.

Foster (1991) also reported subsequent impacts on plant growth and reproduction. Plants in their environment are influenced by different stress such as salinity, drought, tissue damage (scarring), ozone gas, UV and so on. Salinity stress is one of the most important environmental factors which is responsible for the reducing plant productions (Nakano \& Asada, 1980). This may be due to the effect of this high salinity on the physiology, growth and development of plants (Orcutt \&Nilsen , 2000; Bandeoğlu et al., 2004; ElTayeb,2005; Shibli et al., 2007). Dry weight of plants by increasing the salinity degree of soil shows a descending trend and this is due to the impaired absorption of nutrients required for plant growth. It should be noted that growth of shoots is less affected by salinity (Parida \& Das, 2005).

In present study it was concluded that soil salinity did not any negatively affect antioxidant and Physiological Properties of Corn Plant. High soil salinity is because of the present of high salt and this high salt condition favor the plant growth and enzyme level.

\section{Conflict of Interest}

Authors would hereby like to declare that there is no conflict of interests that could possibly arise.

\section{References}

Anderson-Cook CM, Alley MM, Roygard JKF, Khosla R, Noble RB, Doolittle JA (2002) Differentiating soil types using electromagnetic conductivity and crop yield maps. Soil Science Society of America Journal 66:1562-1570. doi:10.2136/sssaj2002.1562.

Bandeoğlu E, Eyidoğan F, Yücel M, Öktem HA (2004) Antioxidant responses of shoots and roots of lentil to $\mathrm{NaCl}-$ salinity stress. Plant Growth Regulation 42: 69-77. doi: 10.1023/B:GROW.0000014891.35427.7b

Boguslawska-Jaworska J, Kaplan JC (1969) A simple screening test for glutathione peroxidase activity in red cells. Clinica Chimica Acta 26: 459-463. doi:10.1016/00098981(69)90074-6. 
Dadkhah A, Griffiths H ( 2005) Comparative effects of nitrogen sources on growth and physiological response of sugar beet plants exposed to salt stress. Abstracts / Comparative Biochemistry and Physiology Part A 141 : S299 - S317.

Dey SK, Dey J, Patra S, Pothal D (2007). Changes in the antioxidative enzyme activities and lipid peroxidation in wheat seedlings exposed to cadmium and lead stress. Brazilian Journal of Plant Physiology 19:53-60.

El-Tayeb MA (2005) Response of barley grain to the interactive effect of salinity and salicylic acid. Plant Growth Regulation 45: 215-224.doi: 10.1007/s10725-005-4928-1

Emdad M, Fardad H (2000) Effect of salinity and humidity on Mlkrdzrt. Iranian Journal of Agricultural Sciences 3: 654-641

Ezzati Ramin, Iranmanesh Mahdi, Saydan Ahmet Cemal (2011) Organic Farming by Using Different Desert Soiles; Could it be an Alternative to Fertilizers? . Journal of Persian gulf (Marine Science) 2:31-36.

Foster JR (1991) Effects of organic chemicals in the atmosphere on terrestrial plants. In: Moser TJ, Barker JR, Tingey DT (Eds.). Ecological Exposure and Effects of airborne toxic chemicals: an overview. Environmental Protection Agency, Corvallis, OR (USA). Environmental Research Lab, USA Pp60-89.

Grattan SR, Grieve CM ( 1992) Mineral element acquisition and growth response of plants grown in saline environments.

Agriculture, Ecosystem \& Environmental 38:275-300. doi:10.1016/0167-8809(92)90151-Z.

Haluschak P (2006) Laboratory methods of soil analysis. Canada-Manitoba Soil Survey Pp 3-133.

Inze D, Montago MV (2002) Oxidative Stress in Plants. Taylor \& Francis Publication, London.

Koren I, Kaufman YJ, Washington R, Todd MC, Rudich Y, Martins VJ, Rosenfeld D (2006) The Bodélé depression-A single spot in the Sahara that provides most of the mineral dust to the Amazon forest. Environmental Research Letters1: 014005. doi:10.1088/1748-9326/1/1/014005.
Kumar A (2008) Environmental Science Appreciation \& Perception. Daya Publishing House, Delhi, India Pp. 45-50.

Nakano Y, Asada K (1980) Spinach chloroplasts scavenge hydrogen peroxide on illumination. Plant and Cell Physiology 21: $1295-1307$

Orcutt DM, Nilsen ET (2000) The Physiology of Plants Under Stress: Soil and Biotic Factors. John Wiley and Sons, New York. Pp 177-235.

Parida AK, Das AB (2005) Salt tolerance and salinity effects on plants: a review. Ecotoxicology and Environmental Safety 60: 324-349. doi:10.1016/j.ecoenv.2004.06.010

Patriquin DE, Blaikie H, Patriquin MJ, Yang C (1993) Onfarm measurements of $\mathrm{pH}$, electrical conductivity and nitrate in soil extracts for monitoring coupling and decoupling of nutrient cycles. Biological Agriculture and Horticulture 9:231272.

Shibli RA, Kushad M, Yousef GG, Lila MA (2007) Physiological and biochemical responses of tomato microshoots to induced salinity stress with associated ethylene accumulation. Plant Growth Regulation 51: 159-169.doi: 10.1007/s10725-006-9158-7.

Smith AE (1995) Handbook of weed management system. CRC press, New York, USA.

Smith JL, Doran JW (1996) Measurement and use of pH and electrical conductivity for soil quality analysis. In: Doran JW; Jones AJ (eds.) Methods for assessing soil quality. Soil Science Society of America Spec. Publ. 49. SSSA, Madison, WI P. 169-185.

Swap R, Garstang M, Greco S, Talbot R, Kallberg P (1992) Saharan dust in Amazon basin. Tellus 44B: 133-149. doi:10.1034/j.1600-0889.1992.t01-1-00005.x.

Vaughan JG, Judd PA (2003) The Oxford Book of Health Foods. Oxford University Press, Oxford, New York.

Zhu X, Zhang J (1997) Anti-transpiration and anti-growth activities in the xylem sap from plants under different types of soil stress. New Phytologist 137: 657-664. doi: 10.1046/j.1469-8137.1997.00869.x. 